\title{
Biological consumption of carbon monoxide in Delaware Bay, NW Atlantic and Beaufort Sea
}

\author{
Huixiang Xie ${ }^{1, *}$, Oliver C. Zafiriou ${ }^{2}$, Thomas P. Umile ${ }^{3,4}$, David J. Kieber ${ }^{3}$ \\ ${ }^{1}$ Institut des Sciences de la Mer de Rimouski, Université du Québec à Rimouski, 310 Allée des Ursulines, Rimouski, \\ Québec G5L 3A1, Canada \\ ${ }^{2}$ Department of Marine Chemistry and Geochemistry, Woods Hole Oceanographic Institution, 266 Woods Hole Road, \\ Woods Hole, Massachusetts 02543, USA \\ ${ }^{3}$ Department of Chemistry, College of Environmental Science and Forestry, State University of New York, 1 Forestry Drive, \\ Syracuse, New York 13210, USA \\ ${ }^{4}$ Present address: Department of Chemistry, The University of Scranton, 223 Monroe Avenue, Scranton, Pennsylvania 18510, USA
}

\begin{abstract}
Microbial consumption is the dominant sink of oceanic carbon monoxide (CO), one of the major carbon-containing photoproducts of chromophoric dissolved organic matter in marine waters. This study presents first-order microbial $\mathrm{CO}$ consumption rate constants $\left(k_{\mathrm{CO}}\right)$ determined using whole-water dark incubations in summer and fall in diverse marine ecosystems covering the Delaware Bay, NW Atlantic, and Beaufort Sea. The microbial CO consumption rate constant, $k_{\mathrm{CO}}$ (mean $\pm \mathrm{SD}$ ) was $1.11 \pm 0.76 \mathrm{~h}^{-1}$ in the Delaware Bay, $0.33 \pm 0.26 \mathrm{~h}^{-1}$ in the coastal Atlantic, $0.099 \pm$ $0.054 \mathrm{~h}^{-1}$ in the open Atlantic, $0.040 \pm 0.012 \mathrm{~h}^{-1}$ in the coastal Beaufort Sea and $0.020 \pm 0.0060 \mathrm{~h}^{-1}$ in the offshore Beaufort Sea. The $k_{\mathrm{CO}}$ in the Delaware Bay covaried with chlorophyll a concentration ([chl a]), rising with increasing salinity in the range 0 to 19 and diminishing with further increasing salinity. The $k_{\mathrm{CO}}$ in the Beaufort Sea is significantly positively correlated with [chl a]. Both the Atlantic and cross-system data sets showed significant positive correlations between $k_{\mathrm{CO}}$ and the product of $[\mathrm{chl} \mathrm{a}]$ and water temperature, suggesting that [chl a] can be used as an indicator of COconsuming bacterial activity in the areas and seasons sampled in this study. Microbial CO consumption was shown to follow Wright-Hobbie kinetics, with variable but low half-saturation concentrations: $\sim \mathrm{nM}$ in the Beaufort Sea and Gulf Stream and 2 to $18 \mathrm{nM}$ in the coastal NW Atlantic. These low half-saturation concentrations suggest that microbial $\mathrm{CO}$ consumption in seawater is at times partly saturated, and that some previous microbial $\mathrm{CO}$ consumption rates determined with the commonly used ${ }^{14} \mathrm{CO}$ method could be underestimates due to the addition of ${ }^{14} \mathrm{CO}$ as a tracer substrate. The present study provides valuable data for coastal and Arctic waters whose $k_{\mathrm{CO}}$ values are poorly or not constrained, including extensive data on the dependence of $k_{\mathrm{CO}}$ on the concentration of CO.
\end{abstract}

KEY WORDS: Carbon monoxide $\cdot$ Microbial consumption $\cdot$ Wright-Hobbie kinetics $\cdot$ Marine waters

\section{INTRODUCTION}

Carbon monoxide (CO) in seawater is produced primarily through solar photolysis of chromophoric dissolved organic matter (CDOM) (Bullister et al. 1982, Conrad et al. 1982, Redden 1982, Gammon \& Kelly 1990, Valentine \& Zepp 1993, Zuo \& Jones 1995) and is lost by microbial consumption (Conrad \& Seiler 1980, 1982, Conrad et al. 1982, Jones \& Morita 1984, Jones
1991, Jones \& Amador 1993, Tolli 2003, Zafiriou et al. 2003) and gas exchange (Conrad et al. 1982, Erickson 1989, Bates et al. 1995, Zuo \& Jones 1995). The interplay between these production and loss processes causes the concentration of $\mathrm{CO}$ ([CO]) in the surface ocean to vary diurnally, usually with large amplitudes (Swinnerton et al. 1970, Conrad et al. 1982, Bates et al. 1995, Johnson \& Bates 1996, Ohta 1997, Ohta et al. 1999, H. Xie et al. unpubl. data). In addition, the verti- 
cal distribution of $\mathrm{CO}$ and its diurnal variation are often modified by vertical mixing and stratification. The motivation of early $\mathrm{CO}$ studies in the ocean mainly stems from the observation that the ocean is a net source of atmospheric CO (Swinnerton et al. 1970, Linnenbom et al. 1973, Swinnerton \& Lamontagne 1973), which plays a key role in regulating the concentration and distribution of the hydroxyl radical in the troposphere (Thompson 1992, Derwent 1995).

Recently, interest in the marine CO cycle has expanded and diversified. As a short-lived photoproduct, $\mathrm{CO}$ is a key species for modeling the couplings among optics, photochemistry, biology, mixing dynamics and gas exchange in the upper ocean (Kettle 1994, Doney et al. 1995, Gnanadesikan 1996, Najjar et al. 2003). Moreover, photoproduction of $\mathrm{CO}$ itself is important, since $\mathrm{CO}$ is the second most abundant carbon-containing product of CDOM photochemistry, with a yield higher than the sum of all the known photochemically produced organic compounds (Mopper et al. 1991). CO has also been used as a proxy species to estimate the rates of photoproduction of dissolved inorganic carbon (DIC), the major carbon photoproduct of $\mathrm{CDOM}_{\text {; }}$ photoproduction of DIC is arguably one of the major terms in the ocean carbon cycle (Johannessen 2000, Mopper \& Kieber 2000).

Microbial consumption is the dominant sink of $\mathrm{CO}$ in seawater compared with air-sea gas exchange under normal turbulent conditions at the sea surface. Rates of microbial CO consumption, along with the outgassing rates, have been utilized to verify or indirectly estimate the total photoproduction of $\mathrm{CO}$ in the global ocean (Zafiriou et al. 2003). As the principal loss term, biological consumption is an important and essential parameter for modeling the biogeochemical behavior of $\mathrm{CO}$ in the upper ocean. Furthermore, microbial CO consumption has attracted much interest in probing the mechanisms of this process (Conrad \& Seiler 1982, Jones \& Morita 1983, 1984, Tolli 2003).

Microbial CO consumption rate constants $\left(k_{\mathrm{CO}}\right)$ have been measured with a variety of approaches. One simple method is to incubate whole-water samples in the dark (called 'whole-water dark incubation' hereafter). Since CO loss kinetics are thought to be first-order (Jones \& Morita 1983, 1984, Johnson \& Bates 1996, Ohta et al. 1999, Zafiriou et al. 2003), exponential decays are fitted to time-series data to obtain CO lossrate constants. This method measures net loss-rate constants at $[\mathrm{CO}]$ slightly below the sample's initial [CO]. A drawback of this method is that samples must be incubated in the dark to prevent interference from photochemical CO production, thereby ignoring any effects of light, such as potential inhibitory effects of solar ultraviolet radiation on bacterial activity (Herndl et al. 1993, Sommaruga et al. 1997).
The more commonly used ${ }^{14} \mathrm{CO}$ method (Jones \& Morita 1983, 1984, Butler et al. 1987, Tolli 2003) yields gross consumption rates at [CO] usually 2 to 10 times higher than oceanic values due to the addition of ${ }^{14} \mathrm{CO}$ as a tracer substrate. Such elevated $\mathrm{CO}$ levels may not lie within the exponential region of first-order or Wright-Hobbie kinetics, and thus lead to an underestimation of CO consumption rates (Tolli 2003). The ${ }^{14} \mathrm{CO}$ method can, however, be used to assess light effects, because it permits samples being incubated in darkness ('dark ${ }^{14} \mathrm{CO}$ incubation' hereafter) or in light ('daylight ${ }^{14} \mathrm{CO}$ incubation' hereafter). CO consumption rate constants can also be derived from exponentially fitting in situ time-series nighttime $\mathrm{CO}$ inventory loss corrected for outgassing ('nighttime inventory loss' method hereafter) (Johnson \& Bates 1996, Ohta 1997, Ohta et al. 1999, H. Xie et al. unpubl. data) or from the difference in daytime- and depth-integrated in situ $\mathrm{CO}$ production between sterilized and non-sterilized samples ('daylight poisoned vs. unpoisoned incubation' hereafter) ( $\mathrm{H}$. Xie et al. unpubl. data). The daylight poisoned versus unpoisoned incubation also takes light effects into account. The latter 2 approaches measure mean rate constants in the water column, and thus cannot resolve possible depth-dependence of $k_{\mathrm{CO}}$.

Previous CO studies were carried out mainly in midand low-latitude open-ocean waters, with little attention paid to coastal and polar waters. The paucity of microbial $\mathrm{CO}$ consumption data in coastal and polar waters adds significant uncertainties to the estimates of the biological CO sink in the global ocean (Zafiriou et al. 2003). This study is not intended to explore the mechanisms of microbial CO consumption, although it may shed some light on them. Instead, it focuses on reporting microbial $\mathrm{CO}$ consumption rate constants in coastal and Arctic marine ecosystems that were littlestudied or unstudied previously. A relatively large data set looking into the kinetics of microbial CO consumption is presented, and its implications for measuring $k_{\mathrm{CO}}$ and marine $\mathrm{CO}$ cycling are discussed. Rate constants from this study are compared with those in the literature determined with different or similar methods.

\section{MATERIALS AND METHODS}

Study areas. Fig. 1 shows sampling sites and cruise data in 3 different regions: the Delaware Bay, the NW Atlantic, and the Canadian Beaufort Sea (including the Mackenzie Shelf and Amundsen Gulf). The Delaware Bay was sampled along a transect with surface salinity ranging from $\sim 0.1$ (near Philadelphia) to $\sim 27$ in the mouth of the estuary. The majority of the NW Atlantic sampling sites were in the coastal areas (surface salin- 
ity $<33$ ) except Stns NA9, NA11, NA14 and NA16 (surface salinity $>34$ ), among which NA11 and NA14 were in the Gulf Stream characterized by high temperature $\left(>28^{\circ} \mathrm{C}\right)$ and high salinity $(>36)$. Stns BS2 to BS4 in the Mackenzie Shelf were strongly influenced by the freshwater plume from the Mackenzie River, the largest river in the North American Arctic. Stn BS10 was characterized by a thin layer $(<6 \mathrm{~m})$ of low-salinity $(\leq 24.8)$ surface water, and Stn BS11 was located near Summers Harbor in a highly productive semi-enclosed bay. The other stations in the Beaufort Sea were in relatively high-salinity offshore waters (surface salinity $\geq 25.5$ ).

Sampling, incubation and analysis. Bulk water was collected using 121 Teflon-coated PVC Niskin or GoFlo samplers; occasionally a hand-held polyethylene bucket was used for taking surface water during the Arctic cruise. CO consumption rate constants determined from bucket samples were not significantly different from rate constants obtained in samples collected from Niskin bottles. Both surface and subsurface water (below the surface mixed layer) were collected in the NW Atlantic and Beaufort Sea, but only surface water was examined in the Delaware Bay. The subsurface $\mathrm{CO}$ concentrations in the Beaufort Sea were, however, often too low to perform incubation experiments. The incubation and analytical techniques followed those of Xie et al. (2002). Briefly, samples were drawn from the samplers directly into acidcleaned 100 or $200 \mathrm{ml}$ all-glass syringes (with a 3-way nylon valve) and incubated in the dark at sea surface temperature (SST) $\left( \pm 1^{\circ} \mathrm{C}\right)$. Subsamples were analyzed sequentially for [CO] at intervals of $<20 \mathrm{~min}$ to $>20 \mathrm{~h}$ (usually 4 points per time series), depending on $\mathrm{CO}$ decay rates, using an analytical system modified from a RGA3 reduction gas analyzer (Trace Analytical). The all-glass syringes permitted acid cleaning and minimized metal contamination that would affect the microbial community during incubations. Samples were usually taken in daytime well after dawn, so [CO] was higher than its local $24 \mathrm{~h}$ average. During an incubation, $\mathrm{CO}$ decayed through a concentration range roughly similar to that occurring in the water column over a daily cycle. Data were plotted as a time series and fitted with an exponential decay curve. Abiotic, dark production of $\mathrm{CO}$, measured by incubating cyanide-poisoned whole water in darkness, was negligible in Arctic waters and in warm offshore waters, but was significant in the Delaware Bay (mean \pm SD: 0.21 $\pm 0.21 \mathrm{nM} \mathrm{h}^{-1}, \mathrm{n}=9$ ). This dark production was not subtracted in fitting the time-series data. Our net rate constants in the Delaware Bay are therefore underestimates.

Kinetic study. The kinetics of microbial CO consumption were studied in the NW Atlantic and Beaufort Sea.
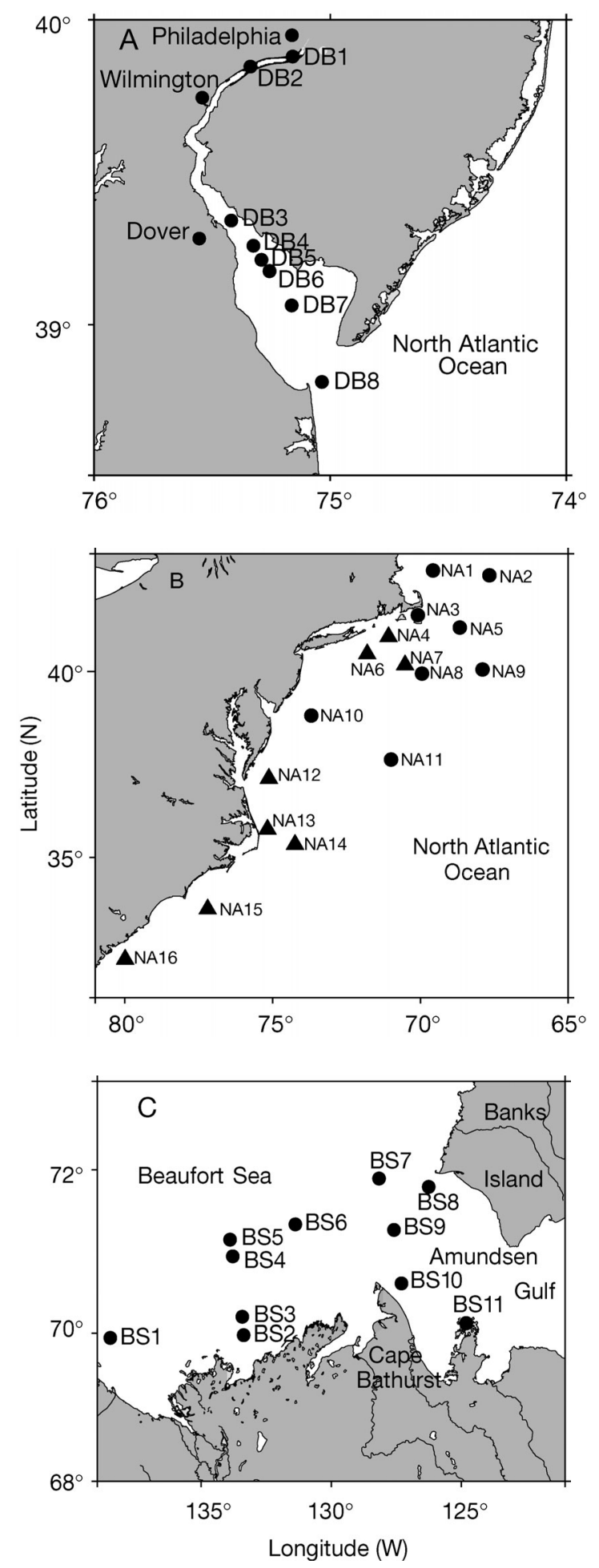

Fig. 1. Maps of study areas showing sampling locations. (A) Delaware Bay; (B) NW Atlantic Ocean; (C) Beaufort Sea. Surveys in Delaware Bay and NW Atlantic were carried out aboard the RV 'Endeavor' from June 25 to July 15, 2002 (•) and from July 15 to August 5, 2003 (ム). Study in Beaufort Sea was conducted aboard CCGS 'Amundsen' from September 28 to October 12, 2003, as part of the Canadian Arctic ShelfExchange Studies (CASES) 
Samples were taken from the above-mentioned samplers into glass jugs. For each water sample, we prepared a supply of very low [CO] water by bubbling with CO-free air in a glass jug in the dark, and also a high [CO] supply by bubbling water with a $10 \mathrm{ppm}$ vol CO standard (Praxair) in a second jug. Different initial CO concentrations were made by drawing different volumes of the 2 bubbled samples into the all-glass syringes and mixing by a rapid twist of the wrist. Each syringe was analyzed close to the time of preparation and then sequentially 2 or 3 times more. Unbubbled samples gave similar rates (within $8 \%$ ) to bubbled samples when the initial [CO] was similar, so bubbling did not seem to have a noticeable influence on $\mathrm{CO}$ microbial activity. Taking mean rates of $\mathrm{CO}$ consumption as differences between adjacent points, we combined all the data for a given water sample into a nonlinear Wright-Hobbie kinetics plot (Wright \& Hobbie 1965). There was often a significant [CO] change between the adjacent points; hence the rates obtained are linear approximations. Since we used nonradioactive substrate and measured [CO], the Wright-Hobbie kinetics equation that we applied to the results of our unfiltered seawater incubations for $\mathrm{CO}$ is identical to the MichaelisMenten kinetics equation for enzyme solutions, i.e. $V=$ $[S] \times V_{\max } /\left(K_{\mathrm{m}}+[S]\right)$, where $V$ is the CO consumption rate at the substrate concentration $[S], V_{\max }$ is the maximum CO consumption rate, and $K_{\mathrm{m}}$ is the substrate concentration at $V_{\max } / 2$. It should be noted, however, that although the same equation is used to analyze our results, the Michaelis-Menten equation typically applies to a 1 substrate-1 enzyme system, while the Wright-Hobbie equation used in our study applies to the whole community uptake (consumption) of CO.

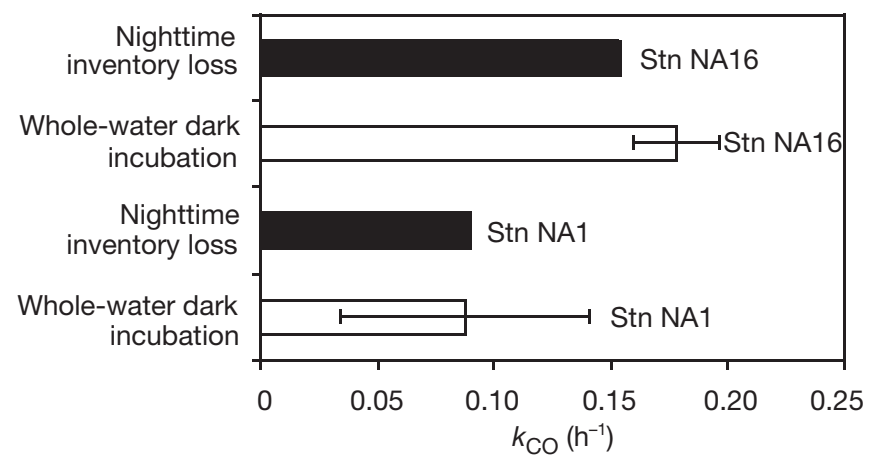

Fig. 2. Method comparison at Stns NA1 and NA16 in the NW Atlantic: rate constants determined from whole-water dark incubation versus nighttime inventory loss. Surface mixedlayer depth is $15 \mathrm{~m}$ at Stn NA1 and $6 \mathrm{~m}$ at Stn NA16. CO inventory was calculated by integrating [CO] from 0 to $20 \mathrm{~m}$ at Stn NA1 and from 0 to $12 \mathrm{~m}$ at Stn NA16. Samples for wholewater dark incubations were taken at 1,5 and $20 \mathrm{~m}$ at Stn NA1 and at 4 and $10 \mathrm{~m}$ at Stn NA16. Rate constants shown for dark incubation method are averages (over depths sampled); error bars $=1 \mathrm{SD}$
Nonlinear least-squares regression analysis was performed to estimate $V_{\max }$ and $K_{\mathrm{m}}$. Linearized forms of the Wright-Hobbie model (e.g. $1 / V=K_{\mathrm{m}} /\left(V_{\max } \times[S]\right)+$ $1 / V_{\max }$ ) have also been widely used for deriving $V_{\max }$ and $K_{\mathrm{m}}$. Some workers recommend the nonlinear over the linearized forms (e.g. Li 1983, Robinson 1985) while others believe that no significant difference exists between the 2 forms for the purpose of estimating these 2 parameters (e.g. Choquet et al. 1988). However, it is generally accepted that the nonlinear form is at least not worse than the linearized forms. For this reason, we chose to analyze our data employing the nonlinear form.

\section{RESULTS}

\section{Method intercomparison}

On 2 occasions in the NW Atlantic (Stns NA1 and NA16), our whole-water dark incubation-derived rate constants were compared with those from the nighttime inventory loss method (Fig. 2). The mean rate constant derived from the whole-water dark incubation method was $0.088 \mathrm{~h}^{-1}$ at Stn NA1 and $0.18 \mathrm{~h}^{-1}$ at Stn NA16; these values match well with the rate constants $\left(0.090\right.$ at NA1 and $0.15 \mathrm{~h}^{-1}$ at NA16) determined with the nighttime inventory loss method. In summer 1999 near the 'Bermuda Atlantic Time-series Study' (BATS) site, H. Xie et al. (unpubl. data) obtained a rate constant of $0.061 \mathrm{~h}^{-1}$ using the nighttime inventory loss method. This value is comparable to the rate constants from the whole-water dark incubation method at Stns NA11 $\left(0.066 \mathrm{~h}^{-1}\right)$ and NA14 $\left(0.070 \mathrm{~h}^{-1}\right)$ in this study, which were located in the Gulf Stream and had physical and biological properties similar to those at the Sargasso Sea site. These inter-comparisons therefore indicate that the wholewater dark incubation method agrees with the nighttime inventory loss method within $20 \%$ or better. Good agreement between the 2 methods was also confirmed by Ohta et al. (1999).

\section{CO consumption rate constants in surface waters}

Typical plots of [CO] versus incubation time are shown in Fig. 3. [CO] decreased exponentially with incubation time on all occasions, and the exponent of the regression equation $\left(k_{\mathrm{CO}}\right)$ decreased rapidly from the warm, high-DOM Delaware Bay waters to the cold, low-DOM offshore Arctic waters. All surface-water ( $\leq 5 \mathrm{~m}) k_{\mathrm{CO}}$ values and corresponding temperatures, salinities and $[\mathrm{chl}$ a] concentrations are presented in Table 1 . The $[\mathrm{chl} a]$ data are included because chl $a$ 
often serves as a proxy for bacterial activity (e.g. Ducklow \& Carlson 1992 [and references therein], Markager 1998, Sherr et al. 2001). The consumption rate constant in the Delaware Bay ranged from $0.26 \mathrm{~h}^{-1}$ at Stn DB8 to $2.44 \mathrm{~h}^{-1}$ at Stn DB4, with an average value of $1.11 \mathrm{~h}^{-1}\left(\mathrm{SD}=0.76 \mathrm{~h}^{-1}, \mathrm{n}=8\right)$. Both $k_{\mathrm{CO}}$ and [chl a] increased with increasing salinity, reached a maximum at salinity 19.1, and then dropped off quickly with a further increase in salinity (Fig. 4A). However, it is evident that the ratio of $k_{\mathrm{CO}}$ : [chl a] is considerably smaller at salinity $>19.1$ than at salinity $<19.1$. Consequently, $k_{\mathrm{CO}}$ is poorly correlated with [chl a] (Table 2). The surface-water temperature in the Delaware Bay changed little $\left(24.1\right.$ to $\left.26.0^{\circ} \mathrm{C}\right)$ during the survey. The effect of the temperature variations on $k_{\mathrm{CO}}$ should therefore be unimportant.

In the NW Atlantic, the rate constant was lowest $\left(\sim 0.07 \mathrm{~h}^{-1}\right)$ at Stns NA9, NA11 and NA14 that were characterized by low [chl a], and highest $\left(0.91 \mathrm{~h}^{-1}\right)$ at Stn NA3 in the highly productive Nantucket Sound (Table 1). The mean $k_{\mathrm{CO}}$ value is $0.099 \mathrm{~h}^{-1}$ ( $\mathrm{SD}=$ $0.054 \mathrm{~h}^{-1}, \mathrm{n}=4$ ) in the open ocean (i.e. Stns with surface salinity $>34)$ and $0.33 \mathrm{~h}^{-1}\left(\mathrm{SD}=0.26 \mathrm{~h}^{-1}, \mathrm{n}=9\right)$ in the coastal zone. The mean $k_{\mathrm{CO}}$ for all stations in the NW Atlantic is $0.26 \mathrm{~h}^{-1}\left(\mathrm{SD}=0.24 \mathrm{~h}^{-1}, \mathrm{n}=13\right)$. At low [chl a], the rate constant covaried with the [chl a], and any effect of temperature was largely overwhelmed. The temperature effect was, however, evident at Stn NA5, characterized by a high [chl a] but a low $k_{\mathrm{CO}}$ and temperature (Fig. 4B). Least-squares correlation analysis indicated that the rate constant was significantly correlated with $A \times t \times[$ chl a] or $\exp (-A / T)$ [chl a] where $t$ (in ${ }^{\circ} \mathrm{C}$ ) and $T$ (in $\mathrm{K}$ ) are temperature and $A$ is the proportionality constant (Table 2 ).

In the Beaufort Sea, the range and mean rate constant were, respectively, 0.028 to $0.058 \mathrm{~h}^{-1}$ and $0.040 \mathrm{~h}^{-1}\left(\mathrm{SD}=0.012 \mathrm{~h}^{-1}, \mathrm{n}=5\right)$ in the near-shore waters, and 0.011 to $0.025 \mathrm{~h}^{-1}$ and $0.020 \mathrm{~h}^{-1}$ (SD = $0.0060 \mathrm{~h}^{-1}, \mathrm{n}=6$ ) in the offshore waters (Table 1). The largest rate constant $\left(0.058 \mathrm{~h}^{-1}\right)$ was at Stn BS11 near Summers Harbor, while the smallest rate constant $\left(0.011 \mathrm{~h}^{-1}\right)$ was at Stn BS7 with the highest salinity (Table 1). Stns BS2 to BS4, situated in the freshwater plume from the Mackenzie River, clearly showed decreasing $k_{\mathrm{CO}}$ with increasing distance from the shore (Table 1, Fig. 1). The temperature of the Arctic waters was always close to $-1^{\circ} \mathrm{C}$, and its effects can thus be ignored. Unfortunately, [ $\mathrm{chl}$ a] was not measured for all of the stations for which $k_{\mathrm{CO}}$ was determined. The available [chl a] data (Table 1), however, showed a significant, negative correlation with salinity $(\mathrm{S})$ in the range 21.4 to 27.5 : [chl $a$ ] $=-0.085 \mathrm{~S}$ $+2.51\left(R^{2}=0.936, n=4\right)$. Since this range covered $80 \%$ of the entire salinity range encountered (20.7 to 28.3), we assumed that this correlation held for the
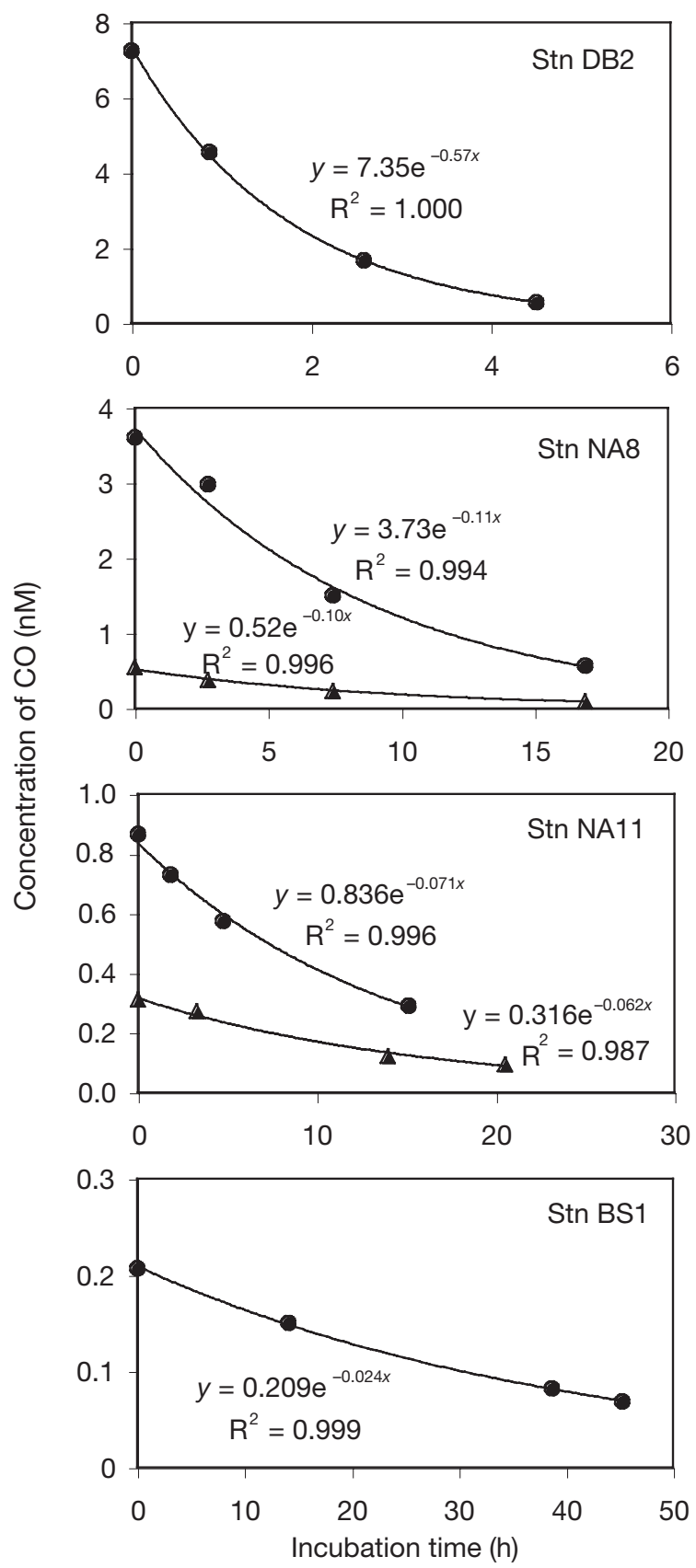

Fig. 3. Typical [CO] versus incubation time plots obtained for Delaware Bay (Stn DB2), coastal NW Atlantic (Stn NA8), Gulf Stream (Stn NA11), and Beaufort Sea (Stn BS1). Continuous lines are exponential fits to data. Sampling depths were: $2.8 \mathrm{~m}$ for Stn DB2, $5 \mathrm{~m}(\bullet)$ and $30 \mathrm{~m}(\boldsymbol{\bullet})$ for Stn NA8, $5 \mathrm{~m}(\bullet)$ and $50 \mathrm{~m}(\mathbf{\Lambda})$ for Stn NA11, and $5 \mathrm{~m}$ for Stn BS1

stations for which chl a concentrations were not determined. The chl a concentrations for these stations were then estimated from the above regression equation. Fig. $4 \mathrm{C}$ shows that the rate constants were significantly positively correlated with the $[\mathrm{chl} a]$. The 
Table 1. Microbial CO consumption rate constant $\left(k_{\mathrm{CO}}\right)$, turnover time $\left(\tau_{\mathrm{CO}}\right)$, and the corresponding water temperature $(t)$ and salinity in the surface waters $(\leq 5 \mathrm{~m})$ of the Delaware Bay, NW Atlantic and Beaufort Sea. n/a: not applicable; nd: not determined; chl a: chlorophyll a

\begin{tabular}{|c|c|c|c|c|c|}
\hline Stn & $t\left({ }^{\circ} \mathrm{C}\right)$ & Salinity & $\operatorname{chl} a\left(\mu g \mathrm{l}^{-1}\right)$ & $k_{\mathrm{CO}}\left(\mathrm{h}^{-1}\right)$ & $\tau_{\mathrm{CO}}(\mathrm{h})$ \\
\hline \multicolumn{6}{|c|}{ Delaware Bay } \\
\hline DB1 & 25.0 & 0.1 & 3.80 & 0.42 & 2.36 \\
\hline DB2 & 25.0 & 0.1 & 3.18 & 0.57 & 1.74 \\
\hline DB3 & 26.0 & 10.0 & 5.63 & 1.26 & 0.79 \\
\hline DB4 & 25.2 & 19.1 & 29.33 & 2.44 & 0.41 \\
\hline DB5 & 25.5 & 10.4 & 7.97 & 1.18 & 0.85 \\
\hline DB6 & 25.5 & 13.7 & 13.42 & 1.94 & 0.52 \\
\hline DB7 & 24.7 & 24.8 & 18.03 & 0.77 & 1.29 \\
\hline DB8 & 24.1 & 26.9 & 9.85 & 0.26 & 3.79 \\
\hline Mean $\pm \mathrm{SD}$ & $25.1 \pm 0.6$ & $13.1 \pm 10.1$ & $11.40 \pm 8.80$ & $1.11 \pm 0.76$ & $1.47 \pm 1.14$ \\
\hline \multicolumn{6}{|l|}{ NW Atlantic } \\
\hline NA1 & 17.8 & 32.3 & 0.35 & 0.096 & 10.44 \\
\hline NA2 & 16.9 & 32.1 & 0.42 & 0.12 & 8.08 \\
\hline NA3 & 22.2 & 32.0 & 3.47 & 0.91 & 1.10 \\
\hline NA4 & 20.9 & 31.6 & 0.90 & 0.29 & 3.45 \\
\hline NA5 & 12.8 & 32.7 & 3.04 & 0.28 & 3.58 \\
\hline NA7 & 23.0 & 33.2 & 0.66 & 0.35 & 2.88 \\
\hline NA8 & 20.2 & 33.1 & 0.16 & 0.11 & 8.88 \\
\hline NA9 & 21.7 & 34.2 & 0.13 & 0.073 & 13.76 \\
\hline NA10 & 25.0 & 32.5 & 0.38 & 0.25 & 4.07 \\
\hline NA11 & 28.5 & 36.0 & 0.080 & 0.071 & 14.14 \\
\hline NA12 & 24.1 & 28.9 & 1.56 & 0.58 & 1.71 \\
\hline NA14 & 28.7 & 36.2 & 0.20 & 0.073 & 13.66 \\
\hline NA16 & 26.4 & 35.6 & 0.51 & 0.18 & 5.56 \\
\hline Mean $\pm \mathrm{SD}$ & $22.2 \pm 4.6$ & $33.1 \pm 2.0$ & $0.91 \pm 1.12$ & $0.26 \pm 0.24$ & $6.52 \pm 4.76$ \\
\hline \multicolumn{6}{|c|}{ Near-shore Beaufort Sea } \\
\hline $\mathrm{BS} 2$ & -0.6 & 20.7 & nd & 0.045 & 22.00 \\
\hline BS3 & -1.0 & 21.4 & 0.73 & 0.039 & 25.50 \\
\hline BS4 & -1.2 & 24.5 & 0.35 & 0.028 & 36.20 \\
\hline BS10 & -0.8 & 24.8 & nd & 0.031 & 32.20 \\
\hline BS11 & 1.0 & nd & nd & 0.058 & 17.20 \\
\hline Mean $\pm \mathrm{SD}$ & $-0.5 \pm 0.9$ & $22.9 \pm 2.10$ & $\mathrm{n} / \mathrm{a}$ & $0.040 \pm 0.012$ & $26.62 \pm 7.65$ \\
\hline \multicolumn{6}{|c|}{ Offshore Beaufort Sea } \\
\hline BS1 & -1.0 & 25.5 & 0.33 & 0.024 & 41.20 \\
\hline BS5 & -1.3 & 25.8 & nd & 0.024 & 41.50 \\
\hline BS6 & -1.5 & 27.5 & 0.22 & 0.019 & 52.40 \\
\hline BS7 & -1.0 & 28.3 & nd & 0.011 & 95.24 \\
\hline BS8 & -0.3 & 27.4 & nd & 0.014 & 69.90 \\
\hline BS9 & -1.0 & 26.0 & nd & 0.025 & 40.20 \\
\hline Mean \pm SD & $-1.0 \pm 0.4$ & $26.8 \pm 1.13$ & $\mathrm{n} / \mathrm{a}$ & $0.020 \pm 0.0060$ & $56.74 \pm 22.01$ \\
\hline
\end{tabular}

Table 2. Regression analysis between microbial $\mathrm{CO}$ consumption rate constant and [chl $a]$ and temperature $\left(t\right.$ in ${ }^{\circ} \mathrm{C}$ and $T$ in $\left.\mathrm{K}\right)$. [chl a] is in $\mu \mathrm{g} \mathrm{l^{-1 }}$. A, $Y_{0}$ : fitting parameters. For the cross-system, temperatures in ${ }^{\circ} \mathrm{C}$ were arbitrarily increased by $2^{\circ} \mathrm{C}$ to offset negative values in Beaufort Sea

\begin{tabular}{|c|c|c|c|c|c|}
\hline Region & Eq. & $A \pm \mathrm{SE}$ & $Y_{0} \pm \mathrm{SE}$ & $\mathrm{R}^{2}$ & $\mathrm{n}$ \\
\hline Delaware Bay & $k_{\mathrm{CO}}=A \times[\operatorname{chl} a]+Y_{0}$ & $0.061 \pm 0.025$ & $0.41 \pm 0.35$ & 0.496 & 8 \\
\hline $\begin{array}{l}\text { NW Atlantic } \\
\quad \leq 5 \mathrm{~m}\end{array}$ & $\begin{array}{l}k_{\mathrm{CO}}=A \times t \times[\mathrm{chl} a]+Y_{0} \\
\ln k_{\mathrm{CO}}=\ln [\operatorname{chl} a]-A / T+Y_{0}\end{array}$ & $\begin{array}{r}0.011 \pm 0.0012 \\
7363.7 \pm 2382.7\end{array}$ & $\begin{aligned} 0.064 & \pm 0.032 \\
24.0 & \pm 8.1\end{aligned}$ & $\begin{array}{l}0.885 \\
0.742\end{array}$ & 13 \\
\hline Profiles & $\begin{array}{l}k_{\mathrm{CO}}=A \times t \times[\mathrm{chl} a]+Y_{0} \\
\ln k_{\mathrm{CO}}=\ln [\mathrm{chl} a]-A / T+Y_{0}\end{array}$ & $\begin{array}{r}0.013 \pm 0.0014 \\
10294.2 \pm 2342.3\end{array}$ & $\begin{aligned}-0.0015 & \pm 0.038 \\
33.8 & \pm 8.0\end{aligned}$ & $\begin{array}{l}0.817 \\
0.656\end{array}$ & 20 \\
\hline All depths & $\begin{array}{l}k_{\mathrm{CO}}=A \times t \times[\mathrm{chl} a]+Y_{0} \\
\ln k_{\mathrm{CO}}=\ln [\mathrm{chl} a]-A / T+Y_{0}\end{array}$ & $\begin{array}{r}0.012 \pm 0.0011 \\
9165.0 \pm 1851.3\end{array}$ & $\begin{aligned} 0.014 & \pm 0.032 \\
29.9 & \pm 6.3\end{aligned}$ & $\begin{array}{l}0.850 \\
0.710\end{array}$ & 26 \\
\hline Beaufort Sea & $k_{\mathrm{CO}}=A \times[\operatorname{chl} a]+Y_{0}$ & $0.053 \pm 0.0046$ & $0.0081 \pm 0.0018$ & 0.944 & 10 \\
\hline Cross-system & $\begin{array}{l}k_{\mathrm{CO}}=A \times(t+2) \times[\mathrm{chl} a]+Y_{0} \\
\ln k_{\mathrm{CO}}=\ln [\mathrm{chl} a]-A / T+Y_{0}\end{array}$ & $\begin{array}{l}0.0029 \pm 0.00030 \\
3583.4 \pm 902.9\end{array}$ & $\begin{array}{l}0.16 \pm 0.049 \\
10.6 \pm 3.1\end{array}$ & $\begin{array}{l}0.692 \\
0.743\end{array}$ & 44 \\
\hline
\end{tabular}



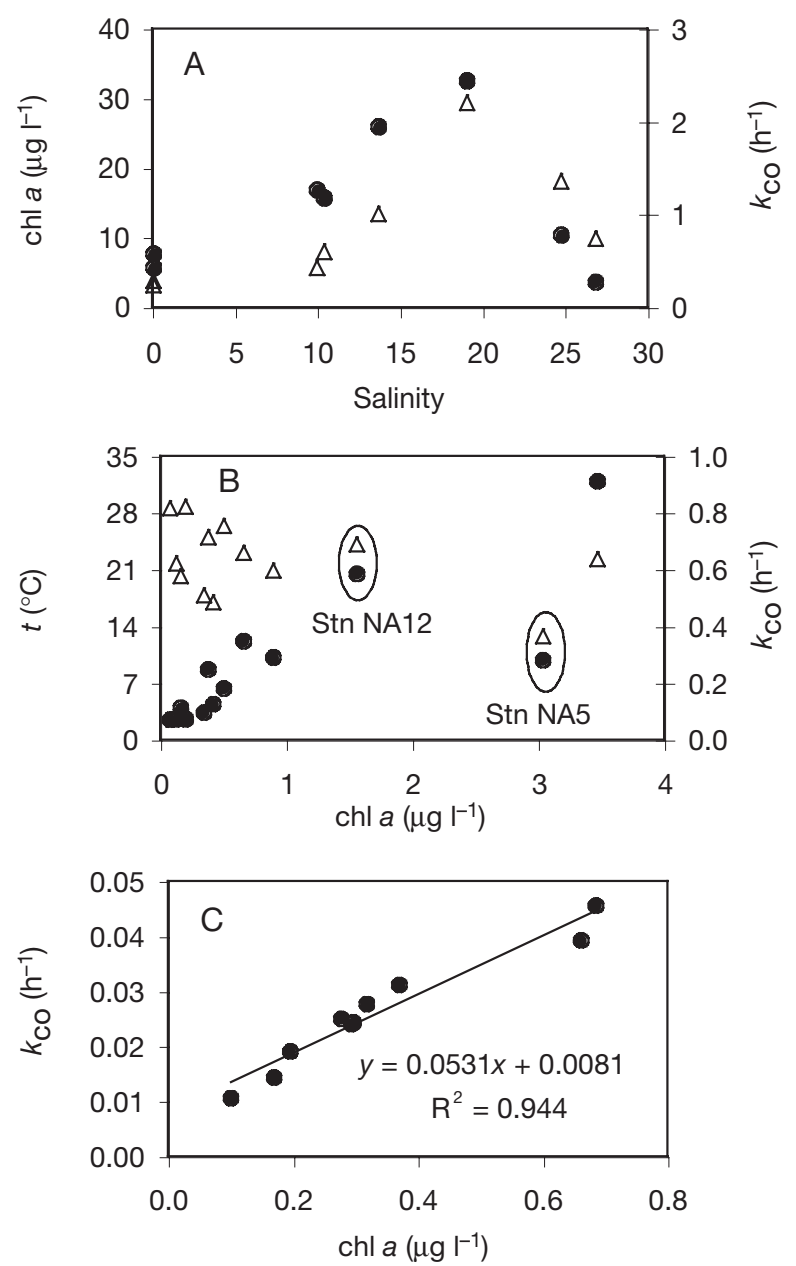

Fig. 4. Relationships between microbial CO consumption rate constant $\left(k_{\mathrm{CO}}\right)$ and other oceanographic variables. (A) Covariation of $k_{\mathrm{CO}}(\bullet)$ with [chl a] $(\Delta)$ along salinity gradient transect in Delaware Bay; (B) water temperature $(\Delta), k_{\mathrm{CO}}(\bullet)$ and [chl a] in NW Atlantic (Stns NA5 and NA12 are labeled to illustrate the potential effect of temperature on $k_{\mathrm{CO}}$ ); (C) correlation of $k_{\mathrm{CO}}$ with [chl a] in Beaufort Sea: best fit of Beaufort Sea data is denoted

data combined from all the ecosystems surveyed (cross-system data hereafter) displayed a positive correlation between $k_{\mathrm{CO}}$ and $A \times t \times[\mathrm{chl} a]$ or $\exp (-A / T)$ [chl a] (Table 2).

The turnover time of $\mathrm{CO}, \tau_{\mathrm{CO}}\left(\tau_{\mathrm{CO}}=1 / k_{\mathrm{CO}}\right)$, for each station is also listed in Table 1 . The ranges and means $\pm \mathrm{SD}$ of $\tau_{\mathrm{CO}}$ were 0.41 to 3.79 and $1.50 \pm 1.14 \mathrm{~h}$ in the Delaware Bay, 1.10 to 14.14 and $6.52 \pm 4.76 \mathrm{~h}$ in the NW Atlantic, and 17.20 to 95.24 and $43.05 \pm 22.65 \mathrm{~h}$ in the Beaufort Sea. The turnover time increased from $25 \mathrm{~min}$ in the warm, organic-rich estuarine water to almost $4 \mathrm{~d}$ in cold, low-DOM offshore Arctic water, a factor of more than 200 .

\section{Vertical distribution of $\boldsymbol{k}_{\mathrm{CO}}$}

Vertical profiles of $k_{\mathrm{CO}}$, [chl a], and temperature in the NW Atlantic are shown in Fig. 5. The vertical distributions of [chl a] and $k_{\mathrm{CO}}$ were fairly homogenous in the surface-mixed layers of Stns NA3, NA5 and NA11. Consumption rate constants below the surface mixed layer (thus lower in situ temperatures) were determined at Stns NA1, NA2, NA8 and NA10. The subsurface rate constants were either similar to (Stn NA8) or considerably smaller (Stns NA1, NA2 and NA10) than

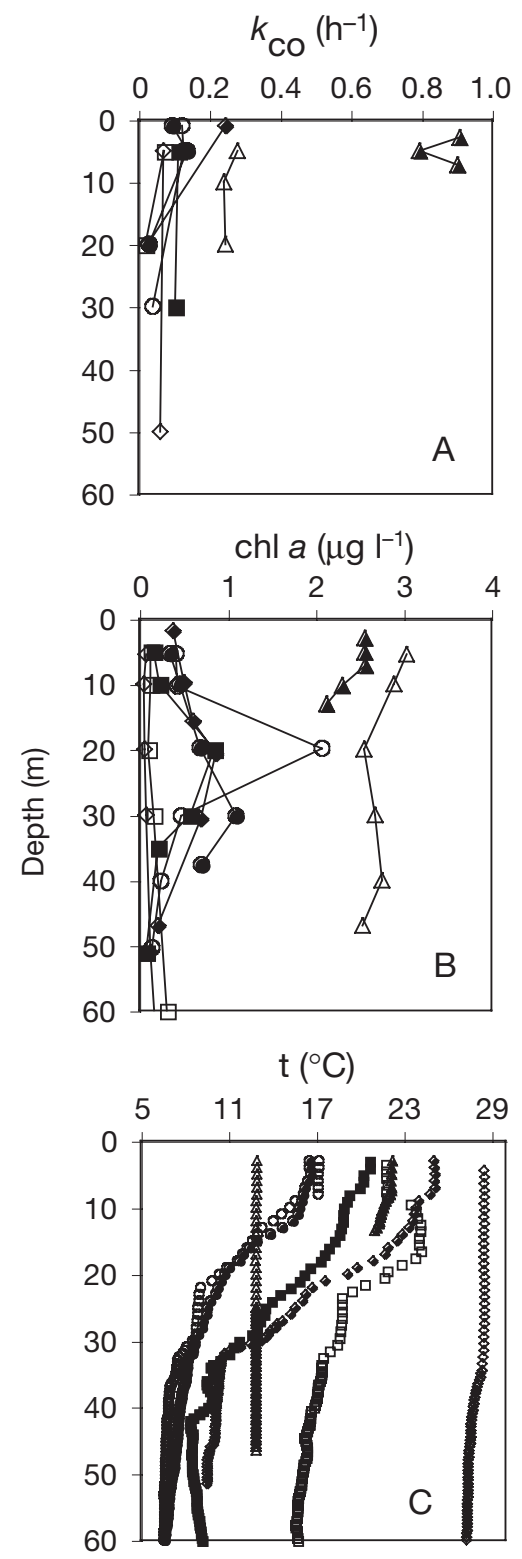

Fig. 5. Vertical profiles of microbial CO consumption rate constant $\left(k_{\mathrm{CO}}\right),[\mathrm{chl} a]$, and temperature in NW Atlantic. (A) $k_{\mathrm{CO}}$;

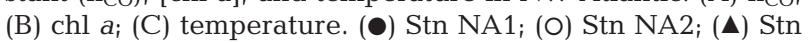
NA3; $(\Delta)$ Stn NA5; $(\square)$ Stn NA8; $(\square)$ Stn NA9; $(\bullet)$ Stn NA10; $(\diamond)$ Stn NA11 
Table 3. Results of nonlinear regression analysis of Wright-Hobbie kinetics model for microbial CO consumption $\left(V=V_{\text {max }}[S] /\right.$ $\left(K_{\mathrm{m}}+[S]\right)$, where $V_{\max }=$ maximum CO consumption rate and $K_{\mathrm{m}}=$ substrate concentration at $\left.V_{\max } / 2\right)$

\begin{tabular}{|lcccrcc|}
\hline Stn & Sampling depth $(\mathrm{m})$ & Sampling time (local) & $\mathrm{R}^{2}$ & $\mathrm{n}$ & $V_{\max } \pm \mathrm{SE}\left(\mathrm{nM} \mathrm{h}^{-1}\right)$ & $K_{\mathrm{m}} \pm \mathrm{SE}(\mathrm{nM})$ \\
\hline NA4 & 0 & $13: 00$ & 0.994 & 8 & $2.05 \pm 0.18$ & $5.3 \pm 0.7$ \\
NA4 & 2 & $18: 00$ & 0.818 & 12 & $2.08 \pm 0.96$ & $6.5 \pm 4.5$ \\
NA4 & 3.5 & $16: 00$ & 0.788 & 10 & $2.40 \pm 1.34$ & $5.6 \pm 4.8$ \\
NA4 & 2 & $09: 00$ & 0.920 & 12 & $3.19 \pm 1.24$ & $7.2 \pm 4.1$ \\
NA6 & 5 & $07: 00$ & 0.821 & 12 & $3.16 \pm 3.20$ & $14.4 \pm 18.1$ \\
NA7 & 3.5 & $23: 00$ & 0.920 & 12 & $4.98 \pm 2.63$ & $12.9 \pm 8.7$ \\
NA12 & 0 & $07: 00$ & 0.998 & 8 & $8.97 \pm 1.04$ & $9.6 \pm 1.5$ \\
NA12 & 0 & $08: 00$ & 0.991 & 12 & $7.45 \pm 1.00$ & $7.2 \pm 1.3$ \\
NA12 & 10 & $08: 00$ & 0.703 & 12 & $1.03 \pm 0.31$ & $2.0 \pm 1.4$ \\
NA13 & 6 & $11: 00$ & 0.899 & 10 & $0.43 \pm 0.07$ & $2.0 \pm 0.7$ \\
NA13 & 2.9 & $09: 00$ & 0.957 & 11 & $2.06 \pm 0.59$ & $5.4 \pm 2.2$ \\
NA14 & 10 & $15: 00$ & 0.707 & 9 & $0.15 \pm 0.04$ & $1.5 \pm 0.9$ \\
NA14 & 15 & $13: 00$ & 0.991 & 8 & $0.26 \pm 0.03$ & $2.9 \pm 0.5$ \\
NA14 & 15 & $02: 00$ & 0.895 & 10 & $0.66 \pm 0.17$ & $2.3 \pm 1.1$ \\
NA15 & 5.2 & $14: 00$ & 0.785 & 8 & $0.55 \pm 0.18$ & $2.8 \pm 1.8$ \\
BS2 & 0 & $15: 30$ & 0.960 & 19 & $0.17 \pm 0.0094$ & $1.51 \pm 0.28$ \\
BS4 & 2.4 & $14: 20$ & 0.942 & 5 & $0.073 \pm 0.011$ & $0.79 \pm 0.73$ \\
& & & & & & \\
\hline
\end{tabular}

those in the mixed layer, whereas the chl a concentrations at these 4 stations were higher at the subsurface depths. Since the subsurface samples were incubated at SST $\left(6\right.$ to $9^{\circ} \mathrm{C}$ greater than the in situ subsurface temperatures), these observations imply that the response time of microbial CO consumption to temperature disturbances might be longer than the incubation times $(<26 \mathrm{~h})$, or that the elevation of the temperature exceeded the optimal temperature range for microbial metabolism and thus suppressed the CO consumption. It was also possible that there were less CO-consuming bacteria below the surface mixed layer or that the subsurface species were less efficient in consuming CO. As no subsurface samples were incubated at in situ temperatures due to experimental constraints, the uncertainties in our subsurface $k_{\mathrm{CO}}$ values are unknown.

Stn NA9 warrants special attention. Both the [chl a] and temperature at $20 \mathrm{~m}$ were comparable to those at $5 \mathrm{~m}$, but $k_{\mathrm{CO}}$ was almost 4 times smaller at $20 \mathrm{~m}$ than at $5 \mathrm{~m}$ (Fig. 5). The temperature (Fig. 5C) and salinity (not shown) profiles indicated that there was an intrusion of warm, saline water between 9 and $24 \mathrm{~m}$, possibly the outside edge of a warm-core Gulf Stream ring. The mixing of this warm and saline water with the relatively cold and less saline local water might dramatically change the species composition and/or the metabolism of the local microbial communities within this layer, leading to the lowest $k_{\mathrm{CO}}\left(0.018 \mathrm{~h}^{-1}\right)$ observed in the NW Atlantic. Despite the uniqueness of Stn NA9 and the unknown uncertainties in the subsurface $k_{\mathrm{CO}}$ values, the CO-consumption rate constants combined from all the profiles or all depths still showed a significant correlation with $A \times t \times\left[\begin{array}{ccl}\mathrm{chl} & \mathrm{a}\end{array}\right]$ or $\exp (-A / T)[$ chl a] (Table 2).

\section{Wright-Hobbie kinetics}

Wright-Hobbie kinetics data for microbial CO consumption in the NW Atlantic and Beaufort Sea are summarized in Table 3, with examples of the WrightHobbie plots shown in Fig. 6. $V_{\max }$ ranged from 0.073 to $8.97 \mathrm{nM} \mathrm{h}^{-1}$, with $47 \%$ of the data $\leq 1 \mathrm{nM} \mathrm{h}^{-1}$ (mean: 0.42), $35 \%$ between 2 and $3 \mathrm{nM} \mathrm{h}^{-1}$ (mean: 2.49), and $18 \%$ between 5 and $9 \mathrm{nM} \mathrm{h}^{-1}$ (mean: 7.13). The highest $V_{\max }$ values were found at Stns NA7 and NA12 in the coastal Atlantic while the lowest values occurred in the Beaufort Sea (Stns BS2 and BS4) and Gulf Stream (Stn NA14, $10 \mathrm{~m}$ depth). $K_{\mathrm{m}}$ spanned a range from $0.79 \mathrm{nM}$ at Stn BS4 to $14.4 \mathrm{nM}$ at Stn NA6; $47 \%$ of the $K_{\mathrm{m}}$ values fell in the range 0.8 to $3 \mathrm{nM}$ (mean: 1.98), $35 \%$ in the range 5 to $7 \mathrm{nM}$ (mean: 6.2 ), and $18 \%$ in the range 9 to $14 \mathrm{nM}$ (mean: 12.3). Similar to $V_{\text {max }}$, the highest $K_{\mathrm{m}}$ values were from the coastal Atlantic while the lowest values were from the Beaufort Sea and Gulf stream. Except on a few occasions, $K_{\mathrm{m}}$ generally increased with increasing $V_{\text {max }}$. $V_{\max }$ and $K_{\mathrm{m}}$ for Stns NA12 and NA13 showed substantial day-to-day variations and depth-dependence, while very little variability was observed at Stns NA4 and NA14 (Table 3). There could have been a number of factors that caused the variability at Stns NA12 and NA13, such as the samples' light histories, tidal mixing, depth-dependence of bacterial population density and species composition.

The kinetic study for the Beaufort Sea samples covered a broader range of substrate concentration than that for the Atlantic samples. The data from Stn BS2 (Fig. 6) show that the microbial CO consumption changed from first-order kinetics at low $[S](<0.8 \mathrm{nM})$ to mixed-order kinetics at intermediate $[S](0.8$ to 

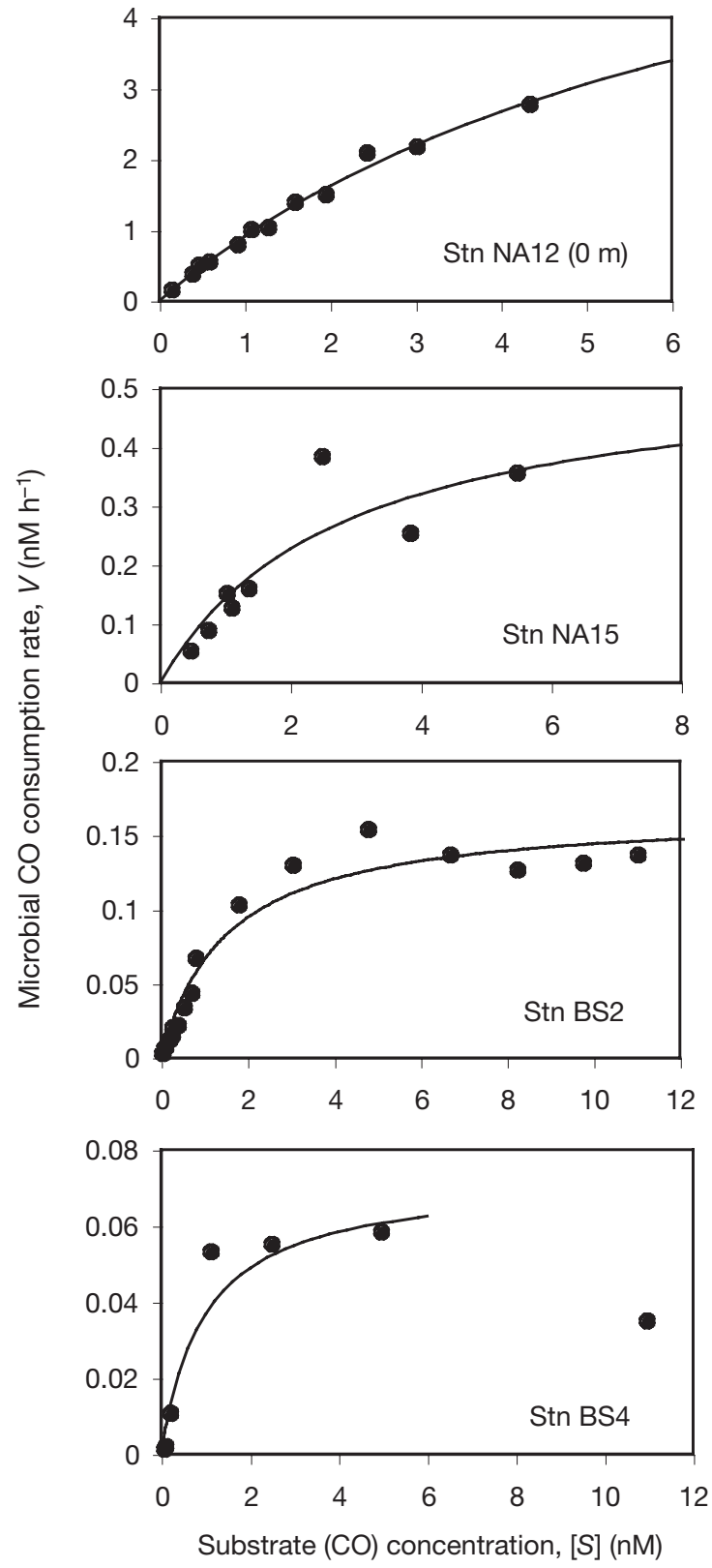

Fig. 6. Examples of Wright-Hobbie plots for microbial CO consumption in NW Atlantic (Stns NA12 and NA15) and Beaufort Sea (Stns BS2 and BS4). Continuous lines: nonlinear least-square fits of data using equation $V=V_{\max }$ $[S] /\left(K_{\mathrm{m}}+[S]\right)$ (to facilitate curve-fitting, last data point for Stn BS4 was not included). See Table 3 for definitions and results of regression analyses

$4.8 \mathrm{nM}$ ), and to saturation (zero-order) kinetics at high $[S](>4.8 \mathrm{nM})$. The upper limit of the $[S]$ tested $(\sim 11 \mathrm{nM})$ was not high enough to reach inhibition (i.e. decreasing $V$ with increasing $[S]$ ). The data from Stn BS4 displayed a significant decrease in $V$ at $[S]$ $\sim 11 \mathrm{nM}$, suggesting that the CO consumption might have changed from saturation kinetics to inhibition kinetics at $[S]$ between 5 and $11 \mathrm{nM}$. However, this argument is speculative due to the lack of sufficient data points at high $[S]$.

\section{DISCUSSION}

\section{Comparison with previous studies}

From the compilation of $k_{\mathrm{CO}}$ values from this and previous studies (Table 4), 2 major points can be made. First, the rate constant decreases from estuaries to coastal zones to open oceans. The highest rate constant $\left(2.44 \mathrm{~h}^{-1}\right)$ was observed in the Delaware Bay; this $k_{\mathrm{CO}}$ value is equivalent to a turnover time of only $25 \mathrm{~min}$. Chemical processes resulting from the high loads of dissolved and particulate materials in the Delaware Bay could not contribute to the fast consumption of $\mathrm{CO}$, since our cyanide-poisoned samples (without the removal of particles) showed a small production of $\mathrm{CO}$, instead of loss of this compound. Second, there is a wide variability of the $k_{\mathrm{CO}}$ in each of these geographic regions. Much of this variability is attributable to different locations and seasons sampled, but a substantial part may also result from different methods employed to determine $k_{\mathrm{CO}}$. Although no direct comparison of the whole-water dark incubation with the dark ${ }^{14} \mathrm{CO}$ incubation was made in this study, the data in Table 4 suggest that the former method yields higher rate constants than the latter. For example, despite the much lower temperatures in the Arctic, the rate constants for the offshore Beaufort Sea determined with the wholewater dark incubation are comparable or even higher than those for the warm Caribbean and Sargasso Seas determined with the dark ${ }^{14} \mathrm{CO}$ incubation (e.g. 0.02 versus $0.01 \mathrm{~h}^{-1}$ ). Furthermore, the dark ${ }^{14} \mathrm{CO}$ incubation-derived rate constant is almost 3 times lower than that derived from the nighttime inventory loss method (Table 4: Tolli \& Taylor 2005 vs. H. Xie et al. unpubl. data). As the whole-water dark incubation agrees with the nighttime inventory loss method, this suggests that the rate constants determined with the whole-water dark incubation would be higher than those obtained with the dark ${ }^{14} \mathrm{CO}$ incubation. Tolli \& Taylor (2005) found that some of their rate constants were underestimated due to the addition of ${ }^{14} \mathrm{CO}$ at concentrations exceeding uptake saturation. To reduce this artifact, they inferred a [CO] value (for each individual cruise) whereby kinetics transitioned from first to zero order, and then normalized these rate constants by this [CO] value. Najjar et al. (2003) employed a 1 D physicalchemical coupled model to simulate the diurnal cycles of surface-water [CO] and $\mathrm{CO}$ inventory obtained from the same field investigation as that of $\mathrm{H}$. Xie et al. 


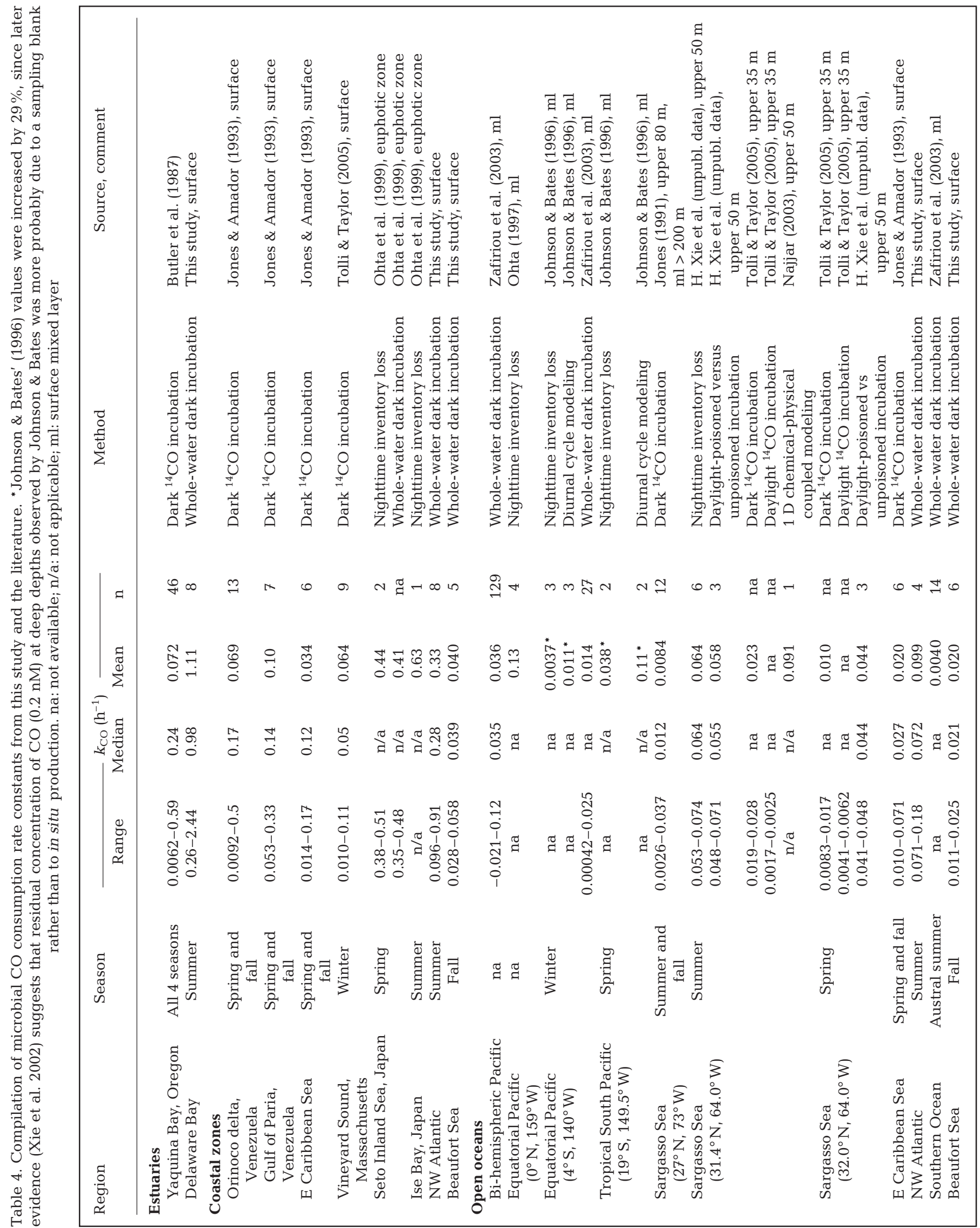


(unpubl. data) and Tolli \& Taylor (2005). The rate constant constrained from the model is $0.091 \mathrm{~h}^{-1}$, which is $42 \%$ higher than the value derived from the nighttime inventory method but 4 times higher than the value of Tolli \& Taylor (2005). In order to account for the CO diurnal cycles near the BATS site, a $k_{\mathrm{CO}}$ of $0.023 \mathrm{~h}^{-1}$ (the mean value of Tolli \& Taylor 2005), would imply a sea-to-air flux of CO that is more than 10 times that estimated from the formula of Wannikhof (1992).

Jones (1991) and Jones \& Amador (1993) added $178 \mathrm{nM}{ }^{14} \mathrm{CO}\left(0.5 \mathrm{ml}{ }^{14} \mathrm{CO}\right.$ in a $25 \mathrm{ml}$ sample; $0.5 \mu \mathrm{Ci}$ $\mathrm{ml}^{-1}$; specific activity $56 \mathrm{mCi} \mathrm{mmol}^{-1}$ ) as a substrate for determining the rate constants in the SW Sargasso Sea and eastern Caribbean Sea, including the Gulf of Paria and Orinoco Delta. This added $\left[{ }^{14} \mathrm{CO}\right]$ was far above the ambient [CO] in the areas they investigated $(<4 \mathrm{nM}$ in the SW Sargasso Sea and 0.9 to $31.6 \mathrm{nM}$ in the E Caribbean). If the half-saturation concentrations for these areas are similar to those reported in this study, the $k_{\mathrm{CO}}$ values of Jones (1991) and Jones \& Amador (1993) might also have been underestimates. It is not possible to assess if similar situations apply to the rate constants in the Yaquina Bay of Oregon reported by Butler et al. (1987), since the amounts of ${ }^{14} \mathrm{CO}$ added to the samples are not given.

Whole-water dark incubation-derived rates could also be overestimated relative to in situ rates due to inhibitory effects of solar ultraviolet-B radiation on microbial activity (Herndl et al. 1993, Sommaruga et al. 1997). Since our samples were taken well after dawn and incubations started soon thereafter, any light effects that persist into the ensuing dark period would affect our rates to some extent. H. Xie et al. (unpubl. data) conducted daylight-poisoned versus unpoisoned incubations in the Sargasso Sea. Bacterial CO consumption was found to be suppressed by 10 to $50 \%$ (in summer) at the surface $(<0.7 \mathrm{~m})$, presumably by light inhibition, but no noticeable effect was observed below $5 \mathrm{~m}$. The daytime- and depth-integrated rate constant derived from this method was only $9 \%$ lower than the rate constant obtained from the nighttime inventory loss method (Table 4), which confirms the speculation made by Zafiriou et al. (2003) that time- and depth-integrated light effects are small. Tolli \& Taylor (2005) performed in situ daylight ${ }^{14} \mathrm{CO}$ incubations and compared them with the dark ${ }^{14} \mathrm{CO}$ incubations. They found that light effects reduced the rate constant by a factor of 10 in summer and a factor of 2 in spring without significant depth-dependence (Table 4), which markedly contrasted with the much weaker light effects observed by H. Xie et al. (unpubl. data). Neither approach examined coupled light-mixing effects on consumption rates, which should partly ameliorate inhibition strictly due to light effects. Further study is required to resolve the contradictory results from these 2 groups.
The $k_{\mathrm{CO}}$ profiles in the NW Atlantic suggest that $k_{\mathrm{CO}}$ is relatively homogenous in the surface mixed layer, a phenomenon also observed by Zafiriou et al. (2003). However, more investigations are needed to elucidate the effect of temperature on microbial CO consumption in subsurface waters, since temperatures below the mixed layer are often considerably lower than those in the mixed layer. Finally, the mean rate constant we determined in the offshore Beaufort Sea is 5 times higher than that in the Southern Ocean reported by Zafiriou et al. (2003) (Table 4). Perhaps this enormous difference reflects the fact that the Arctic Ocean receives large inputs of terrestrial particulate and dissolved organic matter, which favors the growth of microbial communities, while very little landderived materials reach the Antarctic Ocean.

\section{Factors affecting $\boldsymbol{k}_{\mathrm{CO}}$}

This study verifies that $\mathrm{CO}$ consumption is ubiquitous in diverse marine ecosystems encompassing warm and high-DOM estuaries, temperate coastal zones, warm and oligotrophic open-ocean waters, and Arctic near-shore and offshore seas. As for other microbial processes in natural waters, microbial $\mathrm{CO}$ consumption should also depend on bacterial population density, species composition, supply of organic substrates and inorganic nutrients, temperature and $\mathrm{pH}$ (Ducklow \& Carlson 1992, Rivkin et al. 1996, Rivkin \& Anderson 1997). Strong positive correlations between bacterial activity (e.g. productivity) or biomass and [chl a] have been frequently observed, although exceptions exist (e.g. Ducklow \& Carlson 1992, Markager 1998, Sherr et al. 2001). In the Delaware Bay, the co-occurrence of [chl a] and $k_{\mathrm{CO}}$ mid-estuary maxima found in this study are comparable to previously reported midestuary maxima commonly observed for [chl a], phyto-

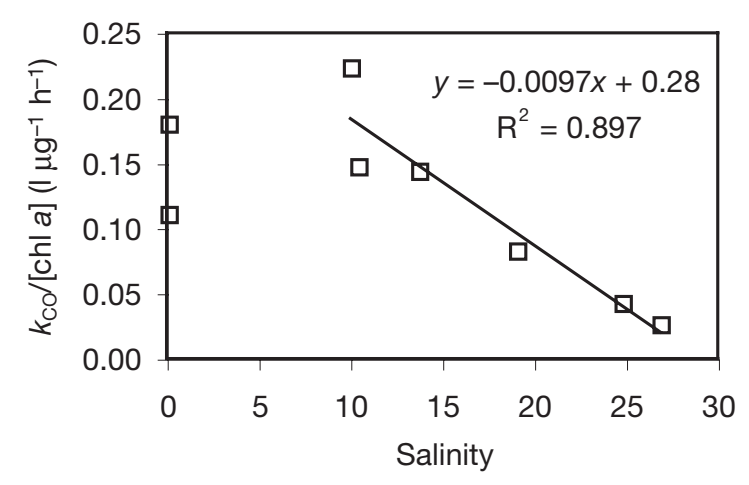

Fig. 7. Chl a normalized microbial $\mathrm{CO}$ consumption rate constant as function of salinity in Delaware Bay. Best fit of the data is denoted (first 2 data points were excluded from regression analysis) 
plankton biomass, bacterial numbers, and bacterial uptake of amino acids (Coffin \& Sharp 1985). Combined with these observations, the significant correlation between $k_{\mathrm{CO}}$ and $A \times t \times[\mathrm{chl} a]$ or $\exp (-A / T) \times[\mathrm{chl}$ a] suggests that [chl a] can be a useful surrogate of bacterial activity, at least for $\mathrm{CO}$-consuming organisms, in the areas and seasons sampled. Our observation might also explain the absence of systematic patterns of $k_{\mathrm{CO}}$ in the inter-hemispheric Pacific Ocean (Zafiriou et al. 2003). As the distributions of [chl a] and surface-water temperature on ocean-basin scales generally show opposite trends, the influences of temperature and [chl a] could largely cancel out.

The small temperature fluctuations (Table 1) and poor correlation of $k_{\mathrm{CO}}$ with [chl a] (Table 2) in the Delaware Bay suggest that factors other than temperature and bacterial activity substantially influence $\mathrm{CO}$ consumption in this environment. Here we used the [chl a]-normalized rate constant (i.e. $k_{\mathrm{CO}} /\left[\begin{array}{cc}\mathrm{chl} & a\end{array}\right]$ ) to speculate about this influence. The [chl a]-normalized rate constant slightly increased from salinity 0.1 to 10.0, and then decreased almost linearly with increasing salinity (Fig. 7). Considering the large salinity range (0.1 to 27.0) covered in the Delaware Bay, the most reasonable cause for this change was a shift from freshwater to marine bacterial species. The good correlation between $k_{\mathrm{CO}}$ and [chl a] in the Beaufort Sea suggests that $\mathrm{CO}$ consumption in this ecosystem mainly responds to primary productivity (and hence bacterial activity). This argument agrees with the fact that the temperature and salinity variations encountered in the Beaufort Sea were small (Table 1). For the NW Atlantic, the combination of temperature and [chl a] could account for $85 \%$ of the $k_{\mathrm{CO}}$ variance (Table 2 ), implying that other variables, including species composition, could not be a dominant control on $k_{\mathrm{CO}}$.

The literature is scant on the phylogeny and identity of bacterial cells responsible for $\mathrm{CO}$ consumption in marine waters. Jones \& Morita (1983) reported that certain chemolithotrophic nitrifying bacteria (including Nitrosococcus oceanus) isolated from both freshwater and marine waters oxidize $\mathrm{CO}$ to $\mathrm{CO}_{2}$. However, in a recent study of the natural bacterial assemblages from the Vineyard Sound in Massachusetts, Tolli (2003) observed that none of the 30 isolates identified to be the CO oxidizers are closely related to known ammonium-oxidizing organisms. Tolli (2003) found that a variety of strains in the $\alpha-, \beta$-, and $\gamma$-subclasses of the Proteobacteria and in the Cytophaga-Flavobacterium-Bacteroides group are able to oxidize $\mathrm{CO}$ at environmentally relevant rates. He further revealed that organisms belonging to the Roseobacter and Paracoccus groups of the $\alpha$-Proteobacteria (collectively known as the 'marine alpha group') are probably the major CO-oxidizers. Given its high contribution to bacterial numbers and biomass in coastal waters (González \& Moran 1997, Suzuki et al. 2001, Zubkov et al. 2002), the Roseobacter group could also be among the important contributors to $\mathrm{CO}$ consumption in the NW Atlantic and Delaware Bay. Preliminary evidence also exists that $\mathrm{CO}$ consumption may be an unrecognized and more general trait of marine heterotrophs than previously suspected (J. D. Tolli pers. comm.).

\section{Wright-Hobbie kinetics}

Kinetic studies on microbial $\mathrm{CO}$ consumption in natural seawater are also meager. Conrad \& Seiler (1982) found a $K_{\mathrm{m}}$ value of $7 \mathrm{nM}$ for a water sample collected from the Atlantic Ocean. Recently, Tolli \& Taylor (2005) employed the ${ }^{14} \mathrm{CO}$ method to study the CO-consumption kinetics for a few samples from the BATS site and the Vineyard Sound in Massachusetts. The $K_{\mathrm{m}}$ value they obtained was $\sim 2 \mathrm{nM}$ at both localities. We collected the first comprehensive data set on CO-consumption kinetics covering the coastal Atlantic, Gulf Stream and Beaufort Sea. Our results (Table 3) confirm the low $K_{\mathrm{m}}$ values observed in the previous studies employing different techniques. Furthermore, this study has shown that the half-saturation concentration varied by over an order of magnitude, with lower values observed in blue and cold waters compared to coastal and warm waters. This observation suggests that microorganisms in different water masses possess enzymes with widely varying affinities for $\mathrm{CO}$.

Surface-water [CO] varies diurnally (and also seasonally in mid- and high-latitude areas) from tenths of a nanomolar to a few nanomolars in the open ocean (Conrad et al. 1982, Bates et al. 1995, H. Xie et al. unpubl. data) to $>10 \mathrm{nM}$ in coastal waters (Ohta 1999, O. C. Zafiriou et al. unpubl. data). Low CO concentrations usually occur in the early morning, while high concentrations usually occur in early to mid afternoon. As the upper-end [CO] in each of these 2 ocean regions is close to the corresponding $K_{\mathrm{m}}$ value, microbial enzymes catalyzing $\mathrm{CO}$ oxidation could at times be partly saturated, particularly in the afternoon (where the unassessed effects of light may also be important for in situ rates). Since naturally-occurring CO concentrations rarely exceed the $K_{\mathrm{m}}$ values by a large factor, microbial $\mathrm{CO}$ consumption in marine waters may be reasonably well approximated by first-order kinetics, as found by this and past studies (Johnson \& Bates 1996, Zafiriou et al. 2003). In cases where the ambient [CO] is so high that $\mathrm{CO}$ consumption substantially deviates from firstorder kinetics (i.e. approaches zero-order kinetics), the Wright-Hobbie kinetics parameters are recommended to more accurately characterize this process. Finally, 
the low $K_{\mathrm{m}}$ values demonstrate that caution should be taken if relatively high levels of $\mathrm{CO}$ are added as a substrate to determine $k_{\mathrm{CO}}$, as in the case for the ${ }^{14} \mathrm{CO}$ method.

\section{CONCLUSIONS}

Microbial CO consumption rate constants decreased from the high-DOM Delaware Bay to the coastal NW Atlantic to the oligotrophic Gulf Stream, and from the mid-latitude Atlantic to the high-latitude Beaufort Sea. The rate constants are fairly homogenous with respect to depth in the surface mixed layer. The turnover time of 25 min observed in the Delaware Bay is the shortest ever reported. The major $(\sim 70 \%)$ variance of the rate constants across the different ecosystems can be accounted for by the variations in [chl a] and temperature, suggesting that [chl a] can serve as an indicator of the activity of CO-consuming bacteria in the areas and seasons sampled. Bacterial CO consumption was observed to follow the Wright-Hobbie kinetics, with variable but low $K_{\mathrm{m}}$ values (0.8 to $14 \mathrm{nM}$ ). These low $K_{\mathrm{m}}$ values imply that some previous rate constants determined with the commonly used ${ }^{14} \mathrm{CO}$ technique are likely to have been underestimated due to the addition of often large amounts of ${ }^{14} \mathrm{CO}$ as a substrate. The effects of temperature on microbial CO consumption remain unelucidated. The present study provides valuable data for refining the estimates of the biological CO sink in the global ocean.

Acknowledgements. We thank R. Morisson and D. Katz for [chl a] data for the Delaware Bay and NW Atlantic, and S. Demers and K. Lacoste for [chl a] data for the Beaufort Sea. We thank the colleagues, captains and crews of the RV 'Endeavor' 372 and 384 cruises, and of the CCGS 'Amundsen' cruise. Z. P. Mei and 3 anonymous reviewers provided critical, constructive comments on the manuscript. T.P.U. was supported on an NSF REU grant (CHE-0243959, D.J.K) for a summer studentship on the RV 'Endeavor' 384 cruise. This study was supported by FQNT and NSERC grants (H.X.), and by NSF grants OCE-0223200 (O.C.Z.) and OCE-0096413 (D.J.K.). Any opinions, findings, conclusions, or recommendations expressed in this paper are those of the authors and do not necessarily reflect the views of the National Science Foundation. This is contribution number 11245 of the Woods Hole Oceanographic Institution.

\section{LITERATURE CITED}

Bates TS, Kelly KC, Johnson JE, Gammon RH (1995) Regional and seasonal variations in the flux of oceanic carbon monoxide to the atmosphere. J Geophys Res 100: 23093-23101

Bullister JL, Guinasso NL Jr, Schink DR (1982) Dissolved hydrogen, carbon monoxide, and methane at CEPEX site. J Geophys Res 87:2022-2034
Butler JH, Jones RD, Garber JH, Gordon LI (1987) Seasonal distribution and turnover of reduced trace gas and hydroxylamine in Yaquina Bay, Oregon. Geochim Cosmochim Acta 51:697-706

Choquet CG, Ferroni GD, Leduc LG, Robinson JA (1988) Statistical considerations associated with the use of the heterotrophic activity method for estimating $V_{\max }$ and $K^{\prime}$ for aquatic environments. Can J Microbiol 34:272-276

Coffin RB, Sharp JH (1985) Amino acid sources for bacterial uptake in the Delaware Estuary. Estuaries 8:10A

Conrad R, Seiler W (1980) Photooxidative production and microbial consumption of carbon monoxide in seawater. FEMS Microbiol Lett 9:61-64

Conrad R, Seiler W (1982) Utilization of traces of carbon monoxide by aerobic oligotrophic microorganisms in ocean, lake, and soil. Arch Microbiol 132:41-46

Conrad R, Seiler W, Bunse G, Giehl H (1982) Carbon monoxide in seawater (Atlantic Ocean). J Geophys Res 87: 8839-8852

Derwent RG (1995) Air chemistry and terrestrial gas emissions: a global perspective. Phil Trans R Soc Lond A 351: 205-217

Doney SC , Najjar RG, Stewart S (1995) Photochemistry, mixing and diurnal cycles in the upper ocean. J Mar Res 53: 341-369

Ducklow HW, Carlson CA (1992) Oceanic bacterial production. In: Marshall KC (ed) Advances in microbial ecology, Vol 12. Plenum Press, New York, p 113-167

Erickson DJ III (1989) Ocean to atmosphere carbon monoxide flux: global inventory and climate implications. Global Biogeochem Cycles 3:305-314

Gammon RH, Kelly KC (1990) Photochemical production of carbon monoxide in surface waters of the Pacific and Indian oceans. In: Blough NV, Zepp RG (eds) Effects of solar ultraviolet radiation on biogeochemical dynamics in aquatic environments. Woods Hole Oceanogr Inst Tech Rep, WHOI-90-09, Woods Hole, MA, p 58-60

Gnanadesikan A (1996) Modeling the diurnal cycle of carbon monoxide: sensitivity to physics, chemistry, biology, and optics. J Geophys Res 101:12177-12191

González JM, Moran MA (1997) Numerical dominance of a group of marine bacteria in the $\alpha$-subclass of the class Proteobacteria in coastal seawater. Appl Environ Microbiol 63:4237-4242

Herndl GJ, Muller-Niklas G, Frick J (1993) Major role of ultraviolet-B in controlling bacterioplankton growth in the surface layer of the ocean. Nature 361:717-719

Johannessen SCH (2000) A photochemical sink for dissolved organic carbon in the ocean. PhD thesis, Department of Oceanography, Dalhousie University, Halifax, Nova Scotia

Johnson JE, Bates TS (1996) Sources and sinks of carbon monoxide in the mixed layer of the tropical South Pacific Ocean. Global Biogeochem Cycles 10:347-359

Jones RD (1991) Carbon monoxide and methane distribution and consumption in the photic zone of the Sargasso Sea. Deep-Sea Res 38:625-635

Jones RD, Amador JA (1993) Methane and carbon monoxide production, oxidation, and turnover times in the Caribbean Sea as influenced by the Orinoco River. J Geophys Res 98:2353-2359

Jones RD, Morita RY (1983) Carbon monoxide oxidation by chemolithotrophic ammonium oxidizers. Can J Microbiol 29:1545-1551

Jones RD, Morita RY (1984) Effects of various parameters on carbon monoxide oxidation by ammonium oxidizers. Can J Microbiol 30:894-899

Kettle AJ (1994) A model of the temporal and spatial distribu- 
tion of carbon monoxide in the mixed layer. MSc thesis, WHOI/MIT Joint Program, Woods Hole Oceanographic Institution, Woods Hole, MA

Li WKW (1983) Consideration of errors in estimating kinetic parameters based on Michaelis-Menten formalism in microbial ecology. Limnol Oceanogr 28:185-190

Linnenbom VJ, Swinnerton JW, Lamontagne RA (1973) The ocean as a source for atmospheric carbon monoxide. J Geophys Res 78:5333-5340

Markager S (1998) Dark uptake of inorganic ${ }^{14} \mathrm{C}$ in oligotrophic oceanic waters. J Plankton Res 20:1813-1836

Mopper K, Kieber DJ (2000) Marine photochemistry and its impact on carbon cycling. In: de Mora S, Demers S, Vernet $M$ (eds) The effects of UV radiation in the marine environment. Cambridge University Press, New York, p 101-129

Mopper K, Zhou XL, Kieber RJ, Kieber DJ, Sikorski RJ, Jones RD (1991) Photochemical degradation of dissolved organic-carbon and its impact on the oceanic carboncycle. Nature 353:60-62

Najjar R, Long R, Zafiriou O, Johnson J (2003) Impact of physical processes on the diurnal cycle of carbon monoxide. Ocean Sci Meet Suppl, Abstract 0532H-IO, EOS Trans AGU, 84(52)

Ohta K (1997) Diurnal variation of carbon monoxide concentration in the Equatorial Pacific upwelling region. J Oceanogr 53:173-178

Ohta K, Inomata Y, Sano A, Sugimura K (1999) Photochemical degradation of dissolved organic carbon to carbon monoxide in coastal seawater. In: Handa N, Tanoue E, Hama T (eds) Dynamics and characterization of marine organic matter. Terra Scientific Publishing, Tokyo

Redden GD (1982) Characteristics of photochemical production of carbon monoxide in seawater, MSc thesis, Oregon State University, Corvallis, OR

Rivkin RB, Anderson MR (1997) Inorganic nutrient limitation of oceanic bacterioplankton. Limnol Oceanogr 42:730-740

Rivkin RB, Anderson MR, Lajzerowicz C (1996) Microbial processes in cold oceans. I. Relationship between temperature and bacterial growth rate. Aquat Microb Ecol 10: $243-254$

Robinson JA (1985) Determining microbial kinetic parameters using nonlinear regression analysis: advantages and limitations in microbial ecology. In: Marshall KC (ed) Advances in microbial ecology, Vol 8. Plenum Press, New York, p 61-114

Sherr EB, Sherr BF, Cowles TJ (2001) Mesoscale variability in bacterial activity in the Northeast Pacific Ocean off Oregon, USA. Aquat Microb Ecol 25:21-30

Editorial responsibility: Otto Kinne (Editor-in-Chief), Oldendorf/Luhe, Germany
Sommaruga R, Obernosterer I, Herndl GJ, Psenner R (1997) Inhibitory effect of solar radiation on thymidine and leucine incorporation by freshwater and marine bacterioplankton. Appl Environ Microbiol 63:4178-4184

Suzuki M, Preston C, Chavez F, DeLong E (2001) Quantitative mapping of bacterioplankton populations in seawater: field tests across an upwelling plume in Monterey Bay. Aquat Microb Ecol 24:117-127

Swinnerton JW, Lamontagne RA (1973) Carbon monoxide in the South Pacific Ocean. Tellus 26:136-142

Swinnerton JW, Linnenbom VJ, Lamontagne RA (1970) The ocean: a natural source of carbon monoxide. Science 167: 984-986

Thompson AM (1992) The oxidizing capacity of the Earth's atmosphere: probable past and future changes. Science 256:1157-1165

Tolli JD (2003) Identity and dynamics of the microbial community responsible for carbon monoxide oxidation in marine environments. PhD thesis, WHOI/MIT Joint Program, Woods Hole, MA

Tolli JD, Taylor CD (2005) Biological CO oxidation rates in the Sargasso Sea and in Vineyard Sound, Massachusetts. Limnol Oceanogr (in press)

Valentine RL, Zepp RG (1993) Formation of carbon monoxide from photodegradation of terrestrial dissolved organic carbon in natural waters. Environ Sci Technol 27:409-412

Wanninkhof R (1992) Relationship between windspeed and gas exchange over the ocean. J Geophys Res 97: 7373-7382

Wright RT, Hobbie JE (1965) The uptake of organic solutes in lake water. Limnol Oceanogr 10:22-28

Xie H, Andrews SS, Martin WR, Miller J, Ziolkowski L, Taylor CD, Zafiriou OC (2002) Validated methods for sampling and headspace analysis of carbon monoxide in seawater. Mar Chem 77:93-108

Zafiriou OC, Andrews SS, Wang W (2003) Concordant estimates of oceanic carbon monoxide source and sink processes in the Pacific yield a balanced global 'blue water' CO budget. Global Biogeochem Cycles 17:1015, doi: 10.1029/2001GB001638

Zubkov M, Fuchs B, Archer S, Kiene R, Amann R, Burkill P (2002) Linking the composition of bacterioplankton to rapid turnover of dissolved dimethylsulphoniopropionate in an algal bloom in the North Sea. Environ Microbiol 3: 304-311

Zuo Y, Jones RD (1995) Formation of carbon-monoxide by photolysis of dissolved marine organic material and its significance in the carbon cycling of the oceans. Naturwissenschaften 82:472-474

Submitted: July 22, 2004; Accepted: November 9, 2004 Proofs received from author(s): March 22, 2005 